\title{
ARTICLE Deorphanization and characterization of the ectopically expressed olfactory receptor OR51B5 in myelogenous leukemia cells
}

\author{
S Manteniotis ${ }^{1,3}$, S Wojcik ${ }^{1,3}, J_{R}$ Göthert ${ }^{2}$, J Dürig $^{2}$, U Dührsen ${ }^{2}$, G Gisselmann ${ }^{1}$ and H Hatt ${ }^{1}$
}

The ectopic expression of olfactory receptors (ORs) in the human body has been of major interest in the past decade. Several studies have reported the expression of ORs not only in healthy tissues such as heart, sperm or skin cells, but also in cancerous tissues of the liver, prostate or intestine. In the present study, we detected the expression of OR51B5 in the chronic myelogenous leukemia (CML) cell line K562 and in white blood cell samples of clinically diagnosed acute myelogenous leukemia (AML) patients by reverse transcription-PCR and immunocytochemical staining. The known OR51B5 ligand isononyl alcohol increased the levels of intracellular $\mathrm{Ca}^{2+}$ in both AML patient blood cells and $\mathrm{K} 562$ cells. With calcium imaging experiments, we characterized in greater detail the OR51B5-mediated signaling pathway. Here, we observed an involvement of adenylate cyclase and the downstream L-type and T-type calcium channels. In addition, the activation of OR51B5 leads to an inhibition of cell proliferation in K562 cells. In western blot experiments, we found that incubation with isononyl alcohol led to a reduction in p38-MAPK (mitogen-activated protein kinase) phosphorylation that might be responsible for the decreased cell proliferation. In the present study, we characterized the OR51B5-mediated signaling pathway downstream of the activation with isononyl alcohol, which leads to reduced proliferation and therefore provide a novel pharmacological target for CML and $A M L$, the latter of which remains difficult to treat.

Cell Death Discovery (2016) 2, 16010; doi:10.1038/cddiscovery.2016.10; published online 9 May 2016

\section{INTRODUCTION}

Olfactory receptor (OR) genes are known to be expressed mainly in the olfactory epithelium, providing rats and humans with the ability to detect volatile odors in their environments. ${ }^{1}$ In humans, $\sim 1000$ different OR genes have been identified, whereas $\sim 400$ of these receptors are known to be functional. The chemical ligands for only $10 \%$ of the functionally expressed ORs are currently described. New expression analysis showed that the expression of OR genes is not necessarily restricted to the nasal epithelium but can be found in almost all parts of the human body. Unfortunately, the physiological function of ectopically expressed ORs has been shown for only a limited number of receptors.

OR1D2 was the first detected OR to be ectopically expressed in spermatogonia and shown to be involved in chemotaxis. ${ }^{2} \mathrm{~A}$ few years later, it was demonstrated that an OR-specific odor stimulation led to serotonin release from enterochromaffine cells of the gut via OR activation. ${ }^{3}$ The prostate-specific G-protein-coupled receptor, also known as OR51E2, is highly expressed in prostate cells and in the prostate cancer cell line LNCaP. ${ }^{4,5}$ In 2009 , the physiological role of OR51E2 was characterized using the agonist $\beta$-lonone in LNCaP cells. ${ }^{6}$ The activation of OR51E2 elicited a rapid $\mathrm{Ca}^{2+}$ increase that caused an inhibition of proliferation via mitogen-activated protein kinase (MAPK) phosphorylation. Recently, a study showed that in hepatocellular carcinoma and in the cell line Huh7, the OR1A2 increased intracellular $\mathrm{Ca}^{2+}$ levels and reduced cell proliferation after (-)-citronellal treatment. ${ }^{7}$ Additional elucidated roles for ORs in various tissue types include involvement in cell cytokinesis, blood pressure regulation and enzyme secretion in the kidneys. ${ }^{8,9}$ In 2014, it could be shown that OR2AT4 could be detected in the skin and in primary keratinocytes, respectively and activated by Sandalore, a synthetic derivate of Sandalwood. ${ }^{10}$ The activation of OR2AT4 led to increase in proliferation and cell migration and to a faster wound healing. A recent study showed that in AML blood cell samples and in the CML cell line K562 the OR2AT4 led to a decreased proliferation and induced apoptosis after activation with Sandalore. ${ }^{11}$ In addition, erythrocyte stimulation could be observed in Sandalore-incubated K562 cells. According to previous studies intracellular $\mathrm{Ca}^{2+}$ can activate several physiological responses, such as differentiation, inhibition of proliferation, apoptosis or chemotaxis, through the activation of downstream mechanisms. ${ }^{12-14}$

In the present work, we used K562 cells as a model for chronic myelogenous leukemia (CML). The K562 cell line was derived from a 53 -year-old CML patient in blast crisis. ${ }^{15}$ This commonly used cell line serves as a model to explore the molecular mechanisms of late-stage human myeloid leukemia. The K562 cell line contains primarily myeloid precursor cells and undifferentiated granulocytes and a few amount of erythrocytes. ${ }^{16,17}$ Unfortunately, most CML-infected patients in blast crisis are physically weak. To investigate the mechanisms in native blood cells of myelogenous leukemia patients, we used blood from acute myelogenous leukemia (AML) patients, due to the high levels of undifferentiated blast cells in the peripheral blood of AML patients.

Here, we show that OR51B5 is activated by its known ligand isononyl alcohol in $\mathrm{K} 562$ cells and in white blood cells of clinically newly diagnosed AML patients. We validated the expression of OR51B5 in K562 cells and in AML blood samples.

\footnotetext{
${ }^{1}$ Department of Cell Physiology, Ruhr-University Bochum, Bochum, Germany and ${ }^{2}$ Department of Hematology, University Hospital Essen, Essen, Germany.

Correspondence: H Hatt (hanns.hatt@rub.de)

${ }^{3}$ These authors contributed equally to this work.

Received 23 December 2015; accepted 12 January 2016; Edited by R Aqeilan
} 
The activation of OR51B5 in K562 cells leads to an inhibition of cancer cell proliferation. Our work provides a novel pharmacological target for CML and AML.

\section{RESULTS}

OR51B5 is expressed in myelogenous leukemia cells In a recent study, using next-generation sequencing we found that OR51B5 is the most highly expressed OR in the chronic myelogenous leukemia cell line K562. ${ }^{11}$ Here, we validated the expression of OR51B5 by reverse transcription (RT)-PCR and immunocytochemical stainings (Figure 1a).

Recently, it was shown using HEK293 cell transfection experiments, that isononyl alcohol is a ligand for OR51B5, which had previously been considered an orphan receptor (personal communication).

To investigate whether the treatment with varying isononyl alcohol concentrations alters the OR51B5 expression level, we incubated K562 cells for a period of time with the odorant and subsequently analyzed the expression level of OR51B5 using qPCR and the $\triangle \triangle C T$ method (Figure 1b). During the incubation of $\mathrm{K} 562$ cells with the OR51B5 agonist, the expression of the receptor was downregulated in a time-dependent manner. After $4 \mathrm{~h}$ of incubation, 0.7-1 mM isononyl alcohol significantly downregulated the expression of the receptor compared with the control. This effect was enhanced by an increased incubation time with the OR51B5 agonist (up to $24 \mathrm{~h}$ ). Next, we validated the RT-PCR experiments using immunocytochemical staining (Figure 1c).
Isononyl alcohol increases the intracellular $\mathrm{Ca}^{2+}$ concentration in K562 cells

It is well known that the binding of ligands to their specific OR activates an intracellular G-protein-mediated signaling cascade, which leads to an increase in intracellular $\mathrm{Ca}^{2+2,3,6,7}$ Here, we sought to investigate if the activation of OR51B5 can similarly increase the intracellular $\mathrm{Ca}^{2+}$ level in $\mathrm{K} 562$ cells. In Figures $2 \mathrm{a}$ and $b$, we have shown that different concentrations of isononyl alcohol (0.3-7 mM) are able to increase intracellular $\mathrm{Ca}^{2+}$ levels to varying degrees. The calculated $\mathrm{EC}_{50}$ of isononyl alcohol in K562 cells was $3.4 \pm 0.2 \mathrm{mM}$. After the application of $1 \mathrm{mM}$ isononyl alcohol on K562 cells, we observed a strong receptor desensitization, as has been observed for other ectopically expressed ORs (Figure $2 \mathrm{c}$ ). ${ }^{7}$ We summarized the mean values for the isononyl alcohol-induced receptor desensitization in Figure 2d. Next, we treated cells with $1 \mathrm{mM}$ isononyl alcohol for $6 \mathrm{~min}$ and observed a short increase in intracellular $\mathrm{Ca}^{2+}$ during the first 2 min of the odor application (Figure 2e). After the first $2 \mathrm{~min}, 60 \%$ of the cells continued to respond to isononyl alcohol with an increase in their cytosolic $\mathrm{Ca}^{2+}$ levels (Figure $2 \mathrm{f}$ ). After applying repetitively $1 \mathrm{mM}$ isononyl alcohol on K562 we observed a strong receptor desensitization, same like it was observed for other ectopically expressed ORs.

Isononyl alcohol activates an AC-mediated signaling pathway in K562

To further investigate the OR51B5-mediated signaling pathway downstream of isononyl alcohol activation, an extracellular $\mathrm{Ca}^{2+}$ chelator was used to determine the source of incoming $\mathrm{Ca}^{2+}$
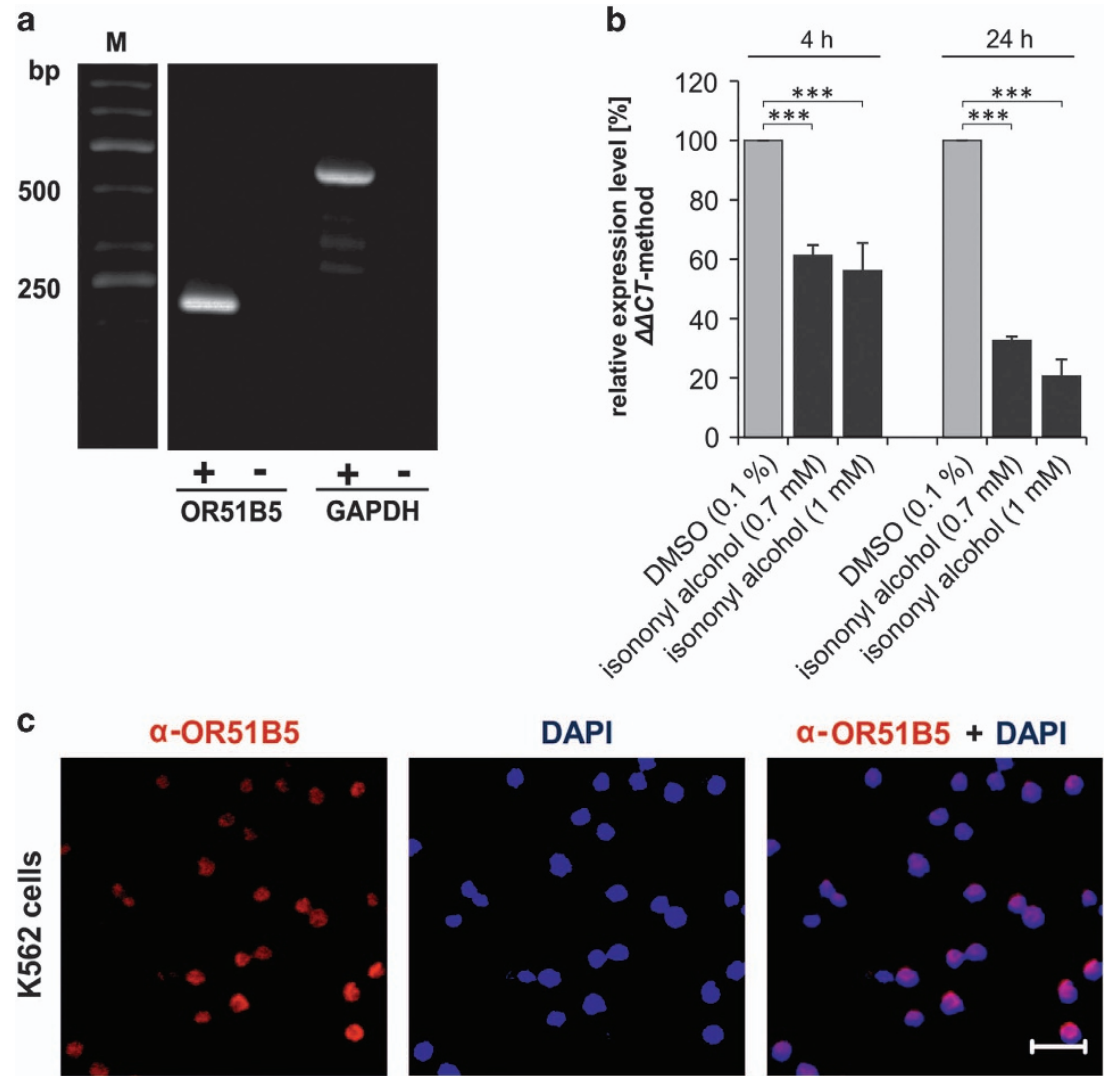

Figure 1. OR51B5 is expressed in the CML cell line K562. (a) RT-PCR experiments show the expression of OR51B5 in K562 cells at the expected size of $\sim 230$ bp. GAPDH was used as a control. (b) qPCR experiments showed that after $4 \mathrm{~h}$ isononyl alcohol incubation OR51B5 expression was significantly decreased. The effect was enhanced by longer stimulation time $(24 \mathrm{~h})$. (c) Immunocytochemical staining with the OR51B5 antibody validates the expression of OR51B5 in K562 cells. DAPI was used to stain the cell nuclei. 


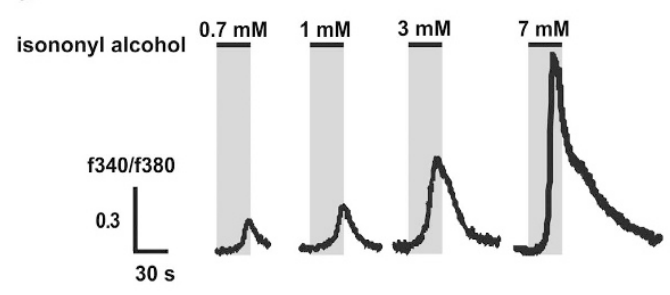

C

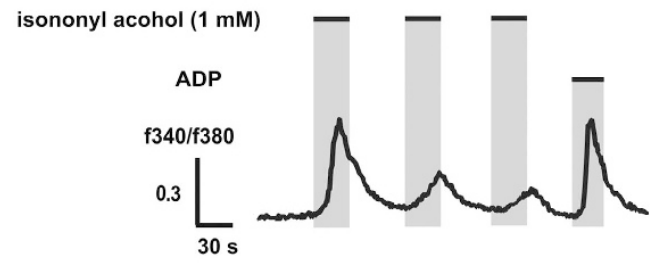

e

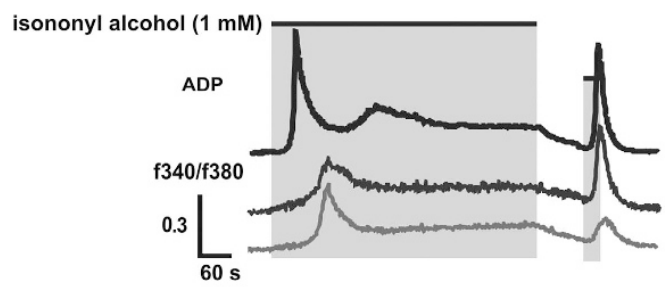

b

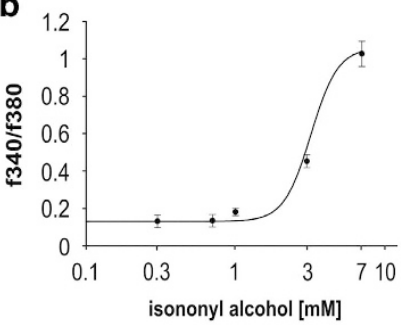

d

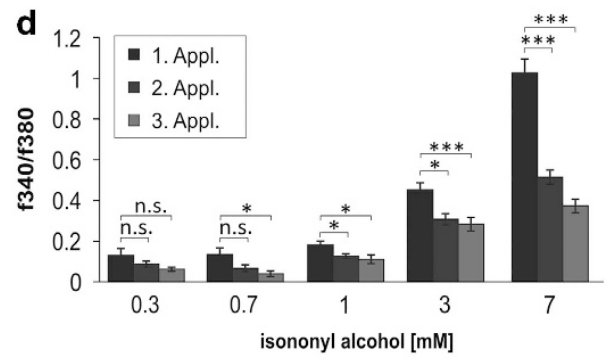

f

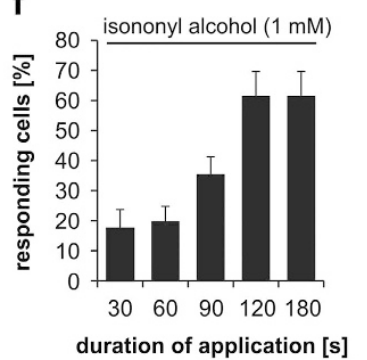

Figure 2. Calcium imaging experiments with the CML cell line K562. (a) Application of different concentrations of isononyl alcohol increased the levels of intracellular $\mathrm{Ca}^{2+}$. (b) The $\mathrm{EC}_{50}$ of isononyl alcohol in $\mathrm{K} 562$ cells was $3.4 \pm 0.2 \mathrm{mM}(n=16)$. (c) Receptor desensitization was observed after repetitive isononyl alcohol stimulation. (d) Summarized results for the receptor desensitization after the application of different isononyl alcohol concentrations. (e) Long-term stimulation $(6 \mathrm{~min})$ with isononyl alcohol increased the cytosolic Ca ${ }^{2+}$ level within the first 2 min of the application time. ADP was used as a positive control to measure cell viability. (f) After 2 min of odor application, a maximum of $\sim 58 \%$ of the cells showed an increase in their intracellular calcium levels.

(Figure 3a). In $\mathrm{Ca}^{2+}{ }_{-}$free extracellular medium, isononyl alcohol was not able to elicit any $\mathrm{Ca}^{2+}$ response in $\mathrm{K} 562$ cells. After rewashing the cells with a $\mathrm{Ca}^{2+}$ containing Ringer's solution, the cells were able to again increase their level of intracellular $\mathrm{Ca}^{2+}$. The co-application of AC inhibitors, such as MDL-12,330A and SQ-22536, significantly reduced the $\mathrm{Ca}^{2+}$ response (Figure 3b; Supplementary Figure 1). A similar effect was observed with the protein kinase A (PKA) inhibitor $\mathrm{H}-89(10 \mu \mathrm{M})$ (Figure 3c). To exclude the involvement of a PLC-mediated pathway, we preincubated K562 cells for 30 min with $30 \mu \mathrm{M}$ of the PLC inhibitor U73122. U73122 had no significant effect on the isononyl alcoholinduced $\mathrm{Ca}^{2+}$ increase (Figure 3d). Next, we wanted to determine which downstream ion channels in the OR-mediated signaling pathway were involved in the calcium influx. In a previous study, the expression levels of several different L-type and T-type calcium channels in $\mathrm{K} 562$ cells were shown. ${ }^{11}$ In accordance with this, Manteniotis et al. ${ }^{11}$ found L-type calcium channels to be involved in the OR2AT4-mediated signaling pathway and to be most likely activated by PKA. In the present work, the same results could be generated for OR51B5. Blocking of either T-type or L-type calcium channels with NNC-55396 $(10 \mu \mathrm{M})$, L-cis diltiazem $(150 \mu \mathrm{M})$ a CNG channel blocker, that is also known to inhibit L-type calcium channels and Verapamil $(20 \mu \mathrm{M})$ significantly decreased the isononyl alcohol-induced $\mathrm{Ca}^{2+}$ response. In Figure $3 \mathrm{f}$ we summarized all of the measured data collected with the calcium imaging experiments in K562 cells.
Isononyl alcohol activates an AC-mediated signaling pathway in native white blood cells of AML patients

To investigate whether this signaling pathway is also activated in native, undifferentiated myeloid cells, we isolated white blood cells from clinically diagnosed AML patients due to their relatively high levels of blast cells in the peripheral bloodstream. During the treatment with isononyl alcohol, the AML cells showed a rapid increase in their amount of intracellular $\mathrm{Ca}^{2+}$ with similar kinetics as those of K562 cells (Figures $4 \mathrm{a}$ and b). In total, $100 \mu \mathrm{M}$ isononyl alcohol could increase the cytosolic $\mathrm{Ca}^{2+}$ level of $\sim 34 \%$ of all AML cells. To investigate whether the same signaling pathway as in K562 cells is involved, we used the same inhibitors that we used on K562 cells. Both the AC inhibitor SQ-22536 and depletion of extracellular $\mathrm{Ca}^{2+}$ significantly reduced the intracellular $\mathrm{Ca}^{2+}$ levels, thus validating the involvement of an AC-mediated signaling pathway downstream of the OR51B5 activation in AML patient blood cells (Figures $4 c$ and d). An overview of the calcium imaging results obtained in AML cells is shown in Figure 4e.

Isononyl alcohol alters the phosphorylation of MAPK in K562 cells An increase in intracellular $\mathrm{Ca}^{2+}$ is known to alter physiological properties, such as proliferation, apoptosis and differentiation, by altering the phosphorylation of MAPKs in a wide variety of cell types. $^{18-21}$ However, the physiological involvement of MAPKs could vary depending on the cell system and the applied substance. ${ }^{22,23}$ In addition, it is widely known that CML is driven by an upregulation of 


\section{a}

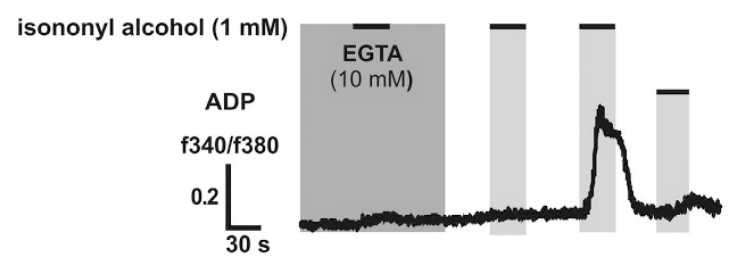

c

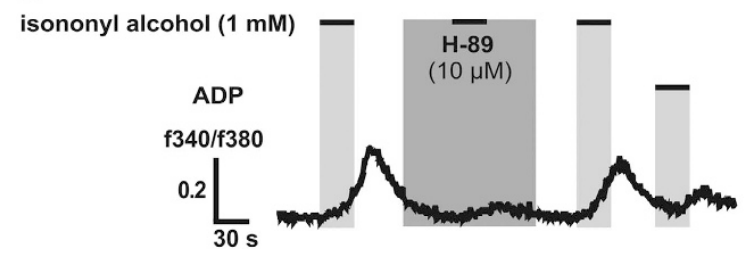

e

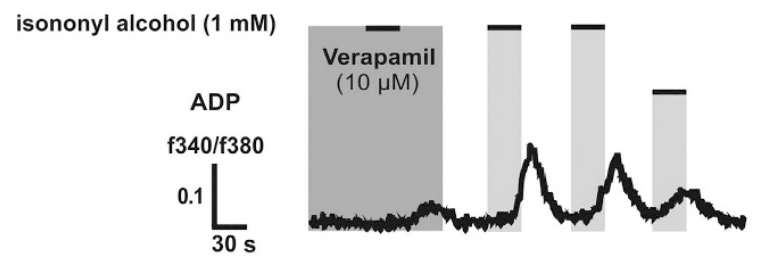

b

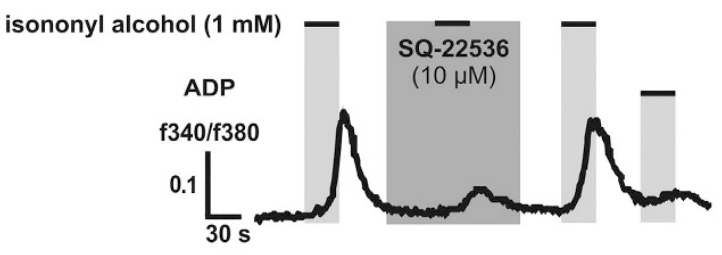

d
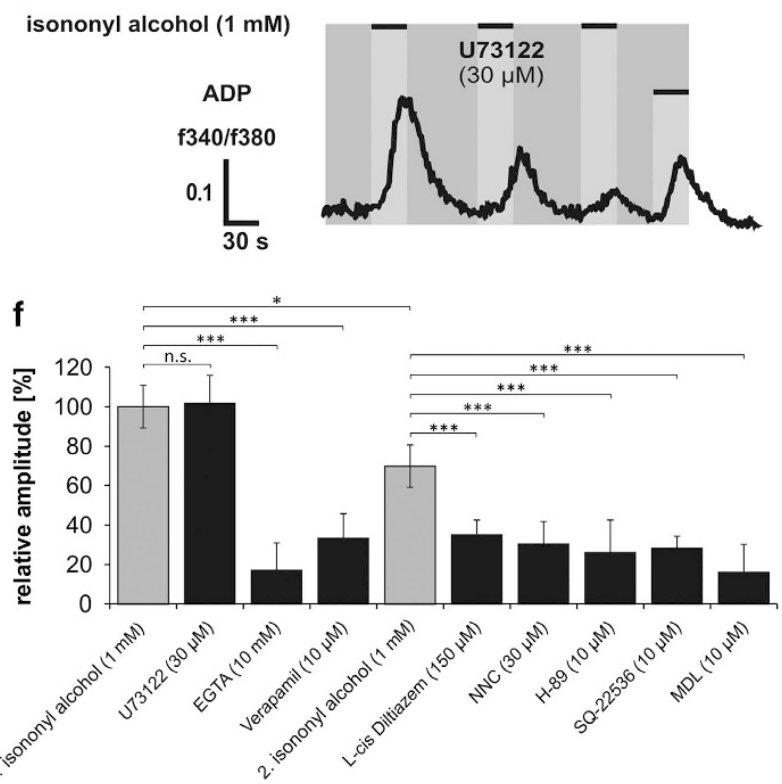

Figure 3. Characterization of the OR51B5-mediated intracellular signaling components. (a) Under $\mathrm{Ca}^{2+}$-free conditions, an increase in cytosolic $\mathrm{Ca}^{2+}$ levels during isononyl alcohol stimulation was almost completely abolished. (b) During the co-treatment with isononyl alcohol and the AC inhibitor SQ-22536, no $\mathrm{Ca}^{2+}$ signals could be detected. (c) The PKA inhibitor H-89 blocked the isononyl alcohol-induced increase in intracellular $\mathrm{Ca}^{2+}$. (d) The PLC inhibitor U73122 could not significantly block the isononyl alcohol-mediated Ca ${ }^{2+}$ increase. (e) L-type calcium channel inhibitor Verapamil abolished the isononyl alcohol-induced $\mathrm{Ca}^{2+}$ increase in $\mathrm{K} 562$ cells. (f) The inhibitor experiments were analyzed relative to the first and second applications of isononyl alcohol.

the fusion protein $B C r-A b l$ in $95 \%$ of all patients. ${ }^{24}$ Therefore, using western blot experiments, we investigated the regulation of $B C r-A b l$ and MAPK phosphorylation after a $1 \mathrm{~h}$ incubation with $300 \mu \mathrm{M}$ isononyl alcohol (Figure 5a). In Figure 5b, we summarized the data regarding $B c r-A b l$, Akt, p44/42 and p38-MAPK phosphorylation. Phosphorylation of $B C r-A b l$ is known to induce proliferation and apoptosis resistance. ${ }^{24-26}$ However, phosphorylation of $B c r-A b l$ was significantly downregulated after $5-15 \mathrm{~min}$ of incubation with isononyl alcohol (Figure 5b). After $30 \mathrm{~min}$ of incubation, Bcr-Abl phosphorylation returned to basal levels. A similar regulatory pattern was observed for p44/42-MAPK (Erk1/2), which is known to be involved in the apoptosis of K562 cells. JNK-MAPK phosphorylation was not affected by isononyl alcohol (data not shown). Akt phosphorylation, which is known to enhance cell survival, was significantly altered after $15-30 \mathrm{~min}$, but not during later stages of isononyl alcohol incubation.

Interestingly, the phosphorylation of p38-MAPK was significantly reduced after $60 \mathrm{~min}$ of odor incubation. The downregulation of p38-MAPK phosphorylation is known to be involved in physiological effects such as proliferation. ${ }^{27}$

It is well known that intracellular $\mathrm{Ca}^{2+}$ can activate a variety of proteins. One such protein that activates many proteins after its phosphorylation is the calcium-calmodulin kinase 2 (CaMKII). Here, we showed that after CaMKII inhibition with the CaMKII inhibitor KN-62 the phosphorylation of p38-MAPK returned to basal levels (Supplementary Figure 2). This suggests that the activation of OR51B5, which leads to $\mathrm{C} \mathrm{Ca}^{2+}$ influx, is responsible for the decreased p38-MAPK phosphorylation.
Isononyl alcohol inhibits the proliferation of K562 cells

To investigate whether the isononyl alcohol-induced alteration in the phosphorylation of p38-MAPK impacts cell proliferation, we used the CyQUANT Proliferation Assay and incubated K562 cells for 5 days with varying concentrations of isononyl alcohol (Figures $6 \mathrm{a}$ and b). K562 cell proliferation after treatment was compared with the control cells. The proliferation of K562 cells exposed to DMSO is not altered compared with the cells treated with medium only. ${ }^{11}$

However, within the first $24 \mathrm{~h}, 0.7-1 \mathrm{mM}$ isononyl alcohol significantly reduced proliferation by $\sim 20 \%$ (Figure 6 a). After 5 days the $\mathrm{K} 562$ cell proliferation remained reduced by $25 \%$. In addition, $300 \mu \mathrm{M}$ isononyl alcohol showed a significant effect after 5 days of incubation on the proliferation of K562 cells (Figure 6b).

\section{DISCUSSION}

In recent years, it has been shown several times that when ectopically expressed in different parts of the human body, olfactory receptors can alter physiological effects after their activation. ${ }^{2,3,6-10,12}$ ORs are expressed at high levels in cancer cells in the prostate, liver or intestine. ${ }^{3,6,7}$ ORs expressed in cancer cells can influence cellular functions, such as proliferation, apoptosis, migration or differentiation. For instance, in the prostate cancer cell line LNCaP and in primary prostate cancer cells, $\beta$-lonone-induced OR activation caused an $\sim 40 \%$ inhibition of cell proliferation. ${ }^{6}$ Similarly, another study reported a reduction in hepatocarcinoma cell proliferation 
a
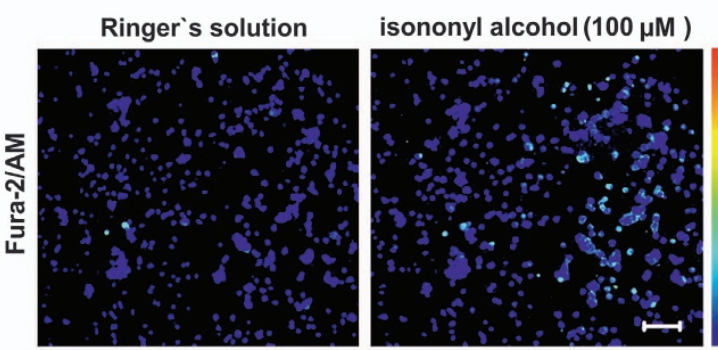

C

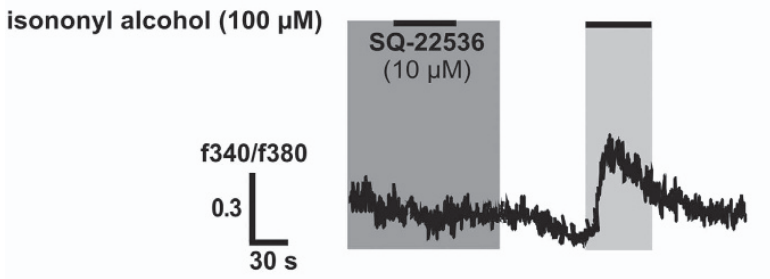

d

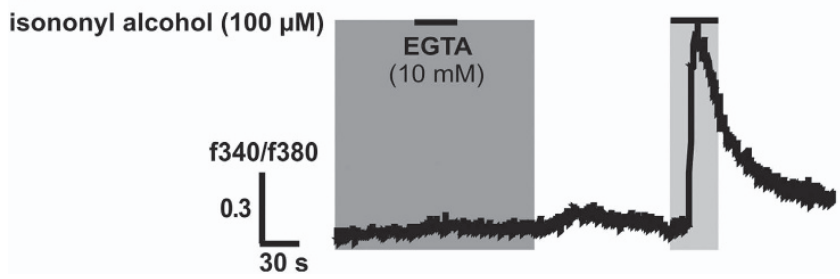

b

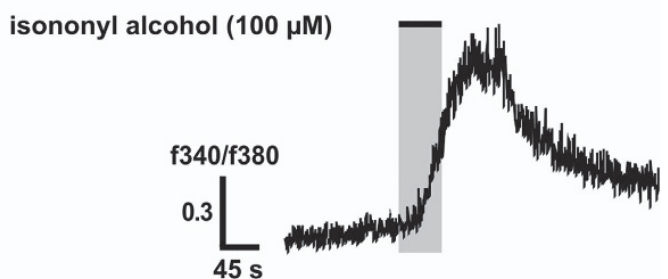

e

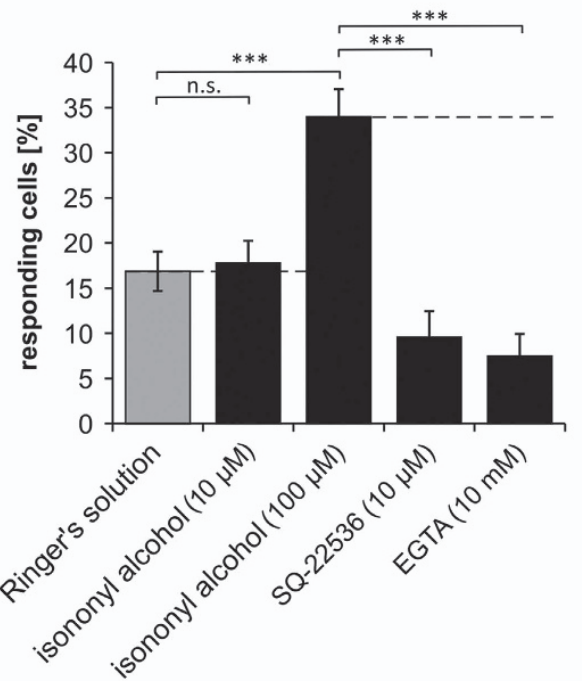

Figure 4. Calcium imaging experiments in the native blood samples of clinically diagnosed AML patients. (a) Native white blood cells from AML patients showed an increase in their intracellular $\mathrm{Ca}^{2+}$ levels during isononyl alcohol application. (b) Representative calcium imaging with the application of $100 \mu \mathrm{M}$ isononyl alcohol. (c) SQ-22536 abolished the isononyl alcohol-induced increase in intracellular Ca ${ }^{2+}$. (d) In absence of extracellular $\mathrm{Ca}^{2+}$ the isononyl alcohol-induced increase in intracellular $\mathrm{Ca}^{2+}$ was abolished. (e) Isononyl alcohol (100 $\left.\mu \mathrm{M}\right)$ led to a significant increase in intracellular $\mathrm{Ca}^{2+}$ in $\sim 35 \%$ of all AML cells. SQ-22536 and the extracellular $\mathrm{Ca}^{2+}$ chelator EGTA reduced the number of responding cells.

mediated by the (-)-citronellal-induced activation of OR1A2. According to our investigations in hepatocarcinoma cells, the OR51B5-mediated increase in intracellular $\mathrm{Ca}^{2+}$ and MAPK phosphorylation is responsible for changes in various physiological processes.

Here, we report the ectopic expression of OR51B5 in the CML cell line $\mathrm{K} 562$ and in white blood cells derived from AML patients. We showed that the activation of OR51B5 leads to an intracellular $\mathrm{Ca}^{2+}$ increase in $\mathrm{K} 562$ cells and in white blood cells of AML patients. An increase in intracellular $\mathrm{Ca}^{2+}$ leads to alternations in cellular functions either by an indirect mechanism or via inhibition of MAPK phosphorylation., 10,11,28-31 The characterization of the OR51B5mediated signaling pathway showed that the receptor activates an AC-mediated pathway in both AML and CML and further activates downstream L-type and T-type calcium channels. Similarly, additional ectopically expressed ORs, such as OR2AT4 in CML, AML and in skin, or the OR1A2 in the hepatocarcinoma cell line Huh7, were reported to involve the AC-mediated signaling pathway. $7,10,11$ However, it is reported that ORs can use different mechanisms, such as activating Src kinases or using a Gq-, Gi-mediated pathway. ${ }^{3,32-34}$

Different concentrations of isononyl alcohol inhibit the proliferation of $\mathrm{K} 562$ cells by inhibiting the phosphorylation of p38-MAPK. Similarly, other studies in K562 cells showed that although an increase in p38-MAPK phosphorylation did not affect the cell proliferation, a decrease in p38-MAPK phosphorylation significantly reduced cell proliferation. ${ }^{35}$

In a previous study we observed the expression of several ORs in acute and chronic myelogenous leukemia. ${ }^{11}$ We characterized the activation of OR2AT4 by Sandalore in K562 cells and in AML blood samples of clinically diagnosed patients. In CML and AML, OR2AT4 is involved in the inhibition of proliferation, the enhancement of cell apoptosis and the differentiation to hemoglobin carrying cells. In the current work, OR51B5 significantly increases the levels of intracellular $\mathrm{Ca}^{2+}$ through an AC-cAMP-mediated pathway and downstream L-type and T-type calcium channels. This signaling pathway is similar to the pathway that has been shown to downstream of OR2AT4 in K562 cells. However, the $\mathrm{EC}_{50}$ of isononyl alcohol for OR51B5 is higher than the $\mathrm{EC}_{50}$ shown for OR2AT4. However, it is comparable to the reported $\mathrm{EC}_{50}$ of $(-)$-citronellal for OR1A2 in Huh7 cells. ${ }^{7}$ This suggests that isononyl alcohol is a low-affinity agonist, which could explain the lower $\mathrm{Ca}^{2+}$ influx and different physiological effects induced by OR51B5. It seems that OR ligands with higher affinities would exert a more significant impact on physiological processes.

For example, the activation of OR51B5 by $0.3-1 \mathrm{mM}$ isononyl alcohol caused an inhibition of $\mathrm{K} 562$ cell proliferation of $\sim 25 \%$. In contrast, the activation of OR2AT4 in K562 cells led to a complete inhibition of cancer cells proliferation. The reason for this discrepancy may be the varying levels of $\mathrm{Ca}^{2+}$ influx, which in turn activates various downstream signaling pathways by phosphorylating MAPKs, Akt or Bcr-Abl.

However, in accordance with our previous study, a decreased p38-MAPK phosphorylation could be the reason for the OR51B5mediated inhibition of proliferation.

Our data suggest that olfactory receptors expressed in CML and $\mathrm{AML}$ are involved in major physiological mechanisms and thus can be considered as new and promising pharmacological antileukemic drug targets for alternative treatments. Several studies describe the anti-cancer effects induced by odorous substances, 
a

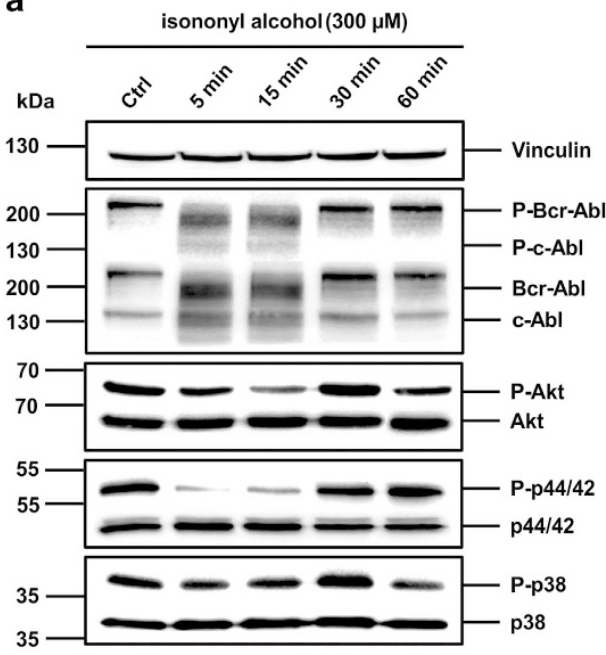

b

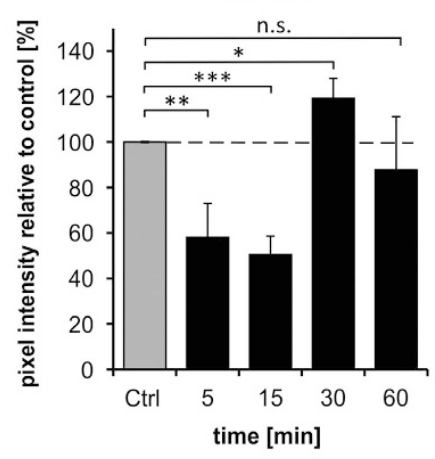

p-p44/42

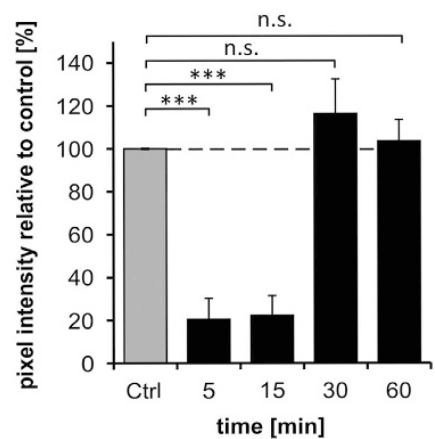

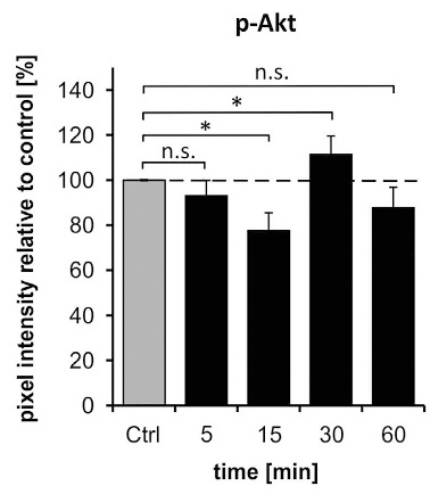

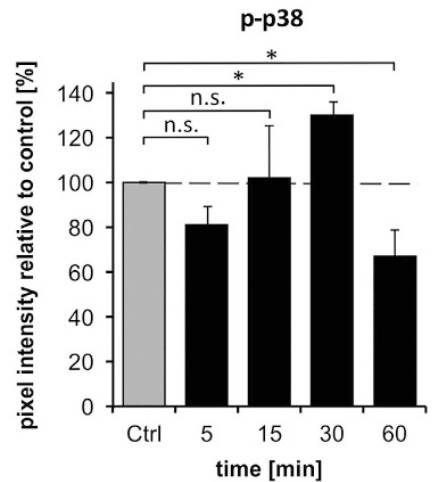

Figure 5. Examination of the protein kinase phosphorylation after isononyl alcohol application. (a) Exemplary western blots are shown for the alterations in the phosphorylation of protein kinases during isononyl alcohol incubation. Vinculin was used as a loading control. (b) Summarized results for the phosphorylation of various protein kinases. After $60 \mathrm{~min}$ of isononyl alcohol incubation, only p38-MAPK phosphorylation was significantly reduced.

such as terpenes, which are components of essential oils. ${ }^{7,36-41}$ In total, half of all produced anti-cancer drugs are composed of natural products or synthetic derivatives. ${ }^{42,43}$ Currently, supportive care and allogeneic transplantation of AML is cured in $<5 \%$ of patients under 60 years of age. ${ }^{44,45}$ Over the past 30 years, the therapeutic treatment of AML has not significantly improved. ${ }^{45}$ Little is known regarding potential pharmacological approaches possibilities to treat this disease, indicating an urgent need for novel treatment modalities.

\section{MATERIALS AND METHODS}

\section{Cell culture}

K562 cells were purchased from LGC Standards GmbH (Wesel, Germany). The cells were cultured at $37^{\circ} \mathrm{C}$ and $6 \% \mathrm{CO}_{2}$ in RPMI-1640 medium (Life Technologies, Carlsbad, CA, USA) containing 10\% (v/v) fetal bovine serum (FBS), 5\% GlutaMAX (Life Technologies) and 100 units/ml penicillin/ streptomycin. ${ }^{17}$ The cells were diluted 1:10 three times per week using freshly prepared medium. Depending on the experiments, the cells were counted and seeded at densities of $1 \times 10^{5}$ cells $/ \mathrm{ml}$ to $1 \times 10^{6}$ cells $/ \mathrm{ml}$. All of the odorants (Sigma-Aldrich, Munich, Germany) were dissolved in DMSO to create stock solutions, which were diluted in medium to a maximal DMSO concentration of $0.1 \%$. Odor-free medium containing $0.1 \%$ DMSO was used in all our experiments as a negative control. To account for any influence of $0.1 \%$ DMSO in the medium, we also performed additional control experiments with DMSO-free medium.

\section{Patient samples}

The analysis of blood samples from AML patients was approved by the ethics committees of the University Hospital Essen and of the Knappschaftskrankenhaus Bochum (ZOKS 3841-10). The patients gave informed consent according to institutional guidelines. In total, 25 patients with various types of AML participated in the study. Blood was drawn from central venous lines. For measuring the effects in AML blood samples, each patient sample was handled separately. The blood samples were incubated with Lymphoprep (Stemcell Technologies, Colonge, Germany) according to the manufacturer's instructions. Erythrocytes were eliminated with $5 \mathrm{~min}$ of incubation with Lysing Buffer (BD Biosciences, Heidelberg, Germany) and subsequent centrifugation.

\section{Cell proliferation}

The cells were seeded into cell culture flasks at a density of $1 \times 10^{5}$ cells $/ \mathrm{ml}$ and treated with varying odorant concentrations $(10-300 \mu \mathrm{M})$ or $0.1 \%$ DMSO as a control. Alternatively, the cells were stimultaneously stimulated with the odor and inhibitors against p38-MAPK, Akt and p44/42-MAPK. To measure the cell viability, a proliferation assay was performed every $24 \mathrm{~h}$ in 96 -well plates using the CyQUANT cell proliferation kit (Life Technologies) according to the manufacturer's protocol. The cell proliferation was measured for 5 days.

\section{RNA isolation and PCR}

Total RNA was extracted from K562 cells using the RNEasy Mini Kit (Qiagen, Hilden, Germany) according to the manufacturer's instructions. Subsequently, DNase I treatment was performed with the TURBO DNA-free Kit (Life Technologies) before complementary DNA (cDNA) was synthesized using the iScript CDNA Synthesis Kit (Bio-Rad Laboratories, Hercules, CA, USA). PCR was conducted with CDNA (the equivalent of $250 \mathrm{ng}$ of total RNA) and specific primer pairs of the following sequences:

OR51B4 forward: 5'CAATGGCACCCTCCTTCTTC3'

OR51B5 reverse: 5'CAAGCAGAATGCCAGACTCG3'

TBP forward: 5'TATAATCCCAAGCGGTTTGC3'

TBP reverse: 5'GCTGGAAAACCCAACTTCTG3'

GAPDH forward: 5'ACCACAGTCCATGCCATCAC3'

GAPDH reverse: 5'TCCCACCACCCTGTTGCTGTA3'

RT-PCR and quantitative real-time PCR ( $\mathrm{QPCR}$ ) were performed with the GoTaq qPCR Master Mix (Promega, Madison, WI, USA). The PCR reactions were performed using the Mastercycler ep realplex (Eppendorf, Hamburg, Germany) with the following cycle profile: 

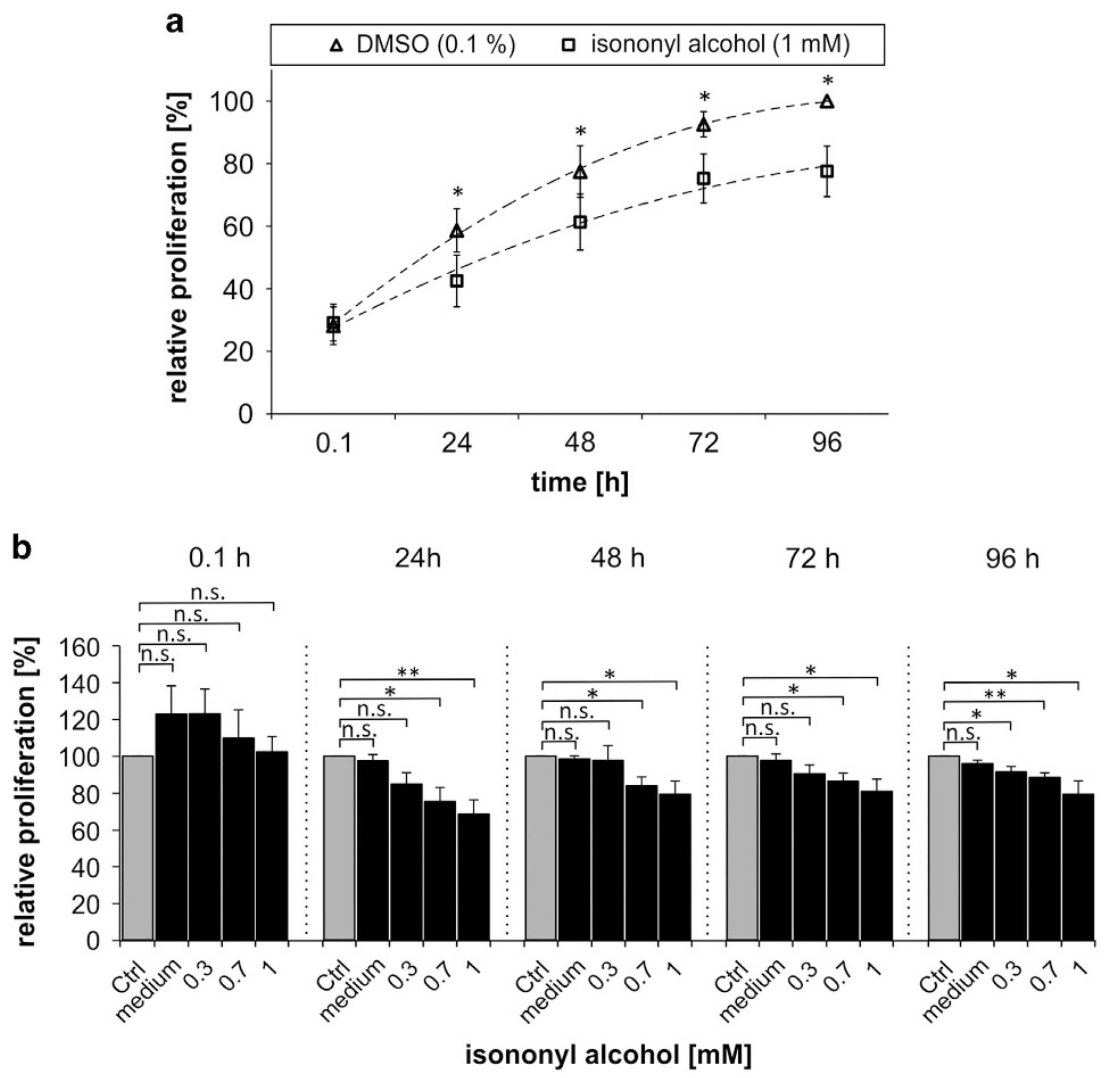

Figure 6. Isononyl alcohol decreases the proliferation of $\mathrm{K} 562$ cells. (a) Isononyl alcohol $(1 \mathrm{mM})$ significantly decreased cell proliferation within $24 \mathrm{~h}$. After 5 days the cell proliferation was reduced up to $25 \%$ compared with the control cells. (b) Control cells (Ctrl: DMSO $0.1 \%$ ) did not exhibit altered cell proliferation compared with cells cultured in DMSO-free RPMI medium. Isononyl alcohol is able to decrease cell proliferation in time- and concentration-dependent manners. The strongest effect was observed after 5 days of incubation with 1 mM isononyl alcohol.

5 min at $95^{\circ} \mathrm{C}$ followed by 40 cycles of $45 \mathrm{~s}$ at $95^{\circ} \mathrm{C}, 45 \mathrm{~s}$ at $60^{\circ} \mathrm{C}$ (for OR51B5, TBP and GAPDH), $45 \mathrm{~s}$ at $72{ }^{\circ} \mathrm{C}$ and a final extension of $10 \mathrm{~min}$ at $72^{\circ} \mathrm{C}$.

The evaluation of the qPCR was performed using the $\Delta \Delta C T$ method as previously. ${ }^{11}$

\section{Flow cytometry}

Erythroid differentiation was assayed by staining K562 cells with an anti-CD235a antibody (Monoclonal Mouse Anti-Human CD235a Glycoporin A/FITC and A/RPE, Clone JC159) after 6-10 days of odor incubation. Flow cytometric data acquisition was performed with an LSRII flow cytometer (BD Bioscience), and the data were analyzed by DIVA (BD Bioscience) and FlowJo software (Treestar, Ashland, OR, USA).

\section{Calcium imaging}

K562 cells were incubated for $20 \mathrm{~min}$ on poly-L-Lysine (Sigma-Aldrich) coated 35-mm dishes with RPMI-1640 medium (Life Technologies), with 10\% FBS, 5\% GlutaMAX and 100 units/ml penicillin/streptomycin and incubated for a further 20 min in RPMI-1640 containing $3 \mu \mathrm{M}$ Fura-2-AM (Molecular Probes, Eugene, Oregon) at $37^{\circ} \mathrm{C}$ and $6 \% \mathrm{CO}_{2}$. White blood cells derived from AML patients were incubated for 20 min on concanavalin $A$ (Sigma-Aldrich) laminated $35-\mathrm{mm}$ dishes. Before assaying the cells, the RPMI-1640 medium was replaced with Ringer's solution $(140 \mathrm{mM}$ $\mathrm{NaCl}, 5 \mathrm{mM} \mathrm{KCl}, 2 \mathrm{mM} \mathrm{CaCl}_{2}, 1 \mathrm{mM} \mathrm{MgCl}$ and $10 \mathrm{mM} \mathrm{HEPES} ; \mathrm{pH}$ 7.3). The calcium imaging experiments were performed as described previously. ${ }^{2,6}$ To create $\mathrm{Ca}^{2+}$-free conditions, we added $10 \mathrm{mM}$ EGTA into a $\mathrm{Ca}^{2+}$-free Ringer's solution. We used the adenylate cyclase inhibitors MDL-12,330 A $(10 \mu \mathrm{M})$, and SQ-22536 $(10 \mu \mathrm{M})$, the phospholipase C inhibitor U73122 $(30 \mu \mathrm{M})$, and the protein kinase A inhibitor $\mathrm{H}-89(10 \mu \mathrm{M})$ to analyze the OR51B5-mediated signaling pathway (all inhibitors were purchased from Sigma-Aldrich). Furthermore, we used various calcium channel blockers, such as NNC-550396 $(30 \mu \mathrm{M})$ that inhibits T-type calcium channels, and
L-cis diltiazem $(150 \mu \mathrm{M})$ that blocks CNGA1 and CNGA3 channels as well as L-type calcium channels (Sigma-Aldrich). Before applying the odorant, the cells were pre- with the blocking solution. To investigate the cell viability $100 \mu \mathrm{M}$ ADP was applied to the cells at the end of each experiment. In previous studies, ADP has been shown to increase the amount of intracellular $\mathrm{Ca}^{2+}$ in K562 cells. ${ }^{46,47}$

Western blotting analysis

K562 cells were treated with $300 \mu \mathrm{M}$ isononyl alcohol for varying amount of time $(5,15,30$ or $60 \mathrm{~min})$ at $37^{\circ} \mathrm{C}$ and $6 \% \mathrm{CO}_{2}$. The cells were harvested and homogenized in lysis buffer (RIPA: $50 \mathrm{mM}$ Tris- $\mathrm{HCl}, 150 \mathrm{mM} \mathrm{NaCl}$, 1 mM EDTA, 1\% Triton X-100, pH 7.4) with protease inhibitor (cOmplete, Roche Applied Science, Basel, Switzerland) and phosphatase inhibitor (PhosSTOP, Roche Applied Science). All western blot experiments were performed as previously described. ${ }^{6,10}$ The detection was performed using the ECL Select Western Blotting Detection System (Amersham Biosciences, $\mathrm{GE}$, Healthcare, Solingen, Germany). We used the polyclonal rabbit antibodies against p44/42-MAPK (cat. no. \#9102), p38-MAPK (cat. no. \#9212), JNK-SAPK (cat. no. \#9252), Akt (cat. no. \#4059) and Bcr-Abl (cat. no. \#2862), as well as the phosphor-specific antibodies against pp44/42-MAPK (cat. no. \#9101), pp38-MAPK (cat. no. \#9211), pJNK-SAPK (cat. no. \#9251), Bcr-Abl (cat. no. \#2864) and pAkt (cat. no. \#4060) (Cell Signaling Technology). For quantification, we used the Java-based software ImageJ 1.46 to calculate the relative pixel intensity. ${ }^{48}$ To investigate the effects of the intracellular $\mathrm{Ca}^{2+}$ increase, we inhibited calmodulin kinase II (CaMKII) with KN-62 (10 $\mu \mathrm{M})$ (Sigma-Aldrich). KN-62 binds directly to CaMKII and leads to its inactivation. ${ }^{49}$ Because CaMKII is activated by $\mathrm{Ca}^{2+}$ and is necessary for the activation of calmodulin, use of this inhibitor allows for investigation of the effects of increased intracellular $\mathrm{Ca}^{2+}$. Therefore, we pre-incubated the cells with $\mathrm{KN}-62$ for at least $60 \mathrm{~min}$ prior to incubation with isononyl alcohol. The effects of $\mathrm{KN}-62$ on isononyl alcohol-treated cells were observed for a further $60 \mathrm{~min}$ after which time the proteins were isolated. To load equal amounts of protein, we determined the total 
protein amount using the Bradford assay (Life Technologies) and optimized the protein loading with Coomassie-staining of SDS-PAGE gels. We used an antibody against the housekeeping protein vinculin (Cell Signaling Technology) as a control in some experiments.

\section{Immunocytochemistry}

For immunocytochemistry experiments, the following antibodies were used: a custom-designed antibody against the C terminus of OR51B5, polyclonal, dilution 1:50 (Eurogentec, Seraing, Belgium); an anti-OR51B5 antibody, polyclonal, dilution 1:25 (Eurogentec); and an anti-caspase-3 antibody, polyclonal, dilution 1:300 (Sigma-Aldrich). Briefly, 5-mm cover slips were coated for $15 \mathrm{~min}$ with poly-L-lysine (Sigm-Aldrich) and air-dried for $30 \mathrm{~min}$. Next, $1-5 \times 10^{6}$ per $\mathrm{ml}$ K562 cells in $60 \mu \mathrm{l}$ were incubated in medium on the coated 5-mm cover slips. The medium was removed, and the cells were fixed in $4 \%$ paraformaldehyde for $20 \mathrm{~min}$ at $4{ }^{\circ} \mathrm{C}$. To wash and permeabilize the membrane, PBS medium including $0.1 \%$ Triton X-100 (Sigma-Aldrich) (PBST) was used. The K562 cells were incubated with primary antibodies, diluted in blocking solution and containing PBST, $1 \%$ fish gelatin and $3 \%$ horse serum for $3 \mathrm{~h}$ at room temperature. After having rewashed the cells three times with PBST, the cells were incubated with a secondary goat anti-rabbit antibody (1:1000) (Alexa Fluor 488, Life Technologies) and 4'6'-diamidino-2-phenylindole (1:300) in blocking solution for $1 \mathrm{~h}$ at room temperature. Next, the cells were washed again with PBST and mounted on a slide with ProLong Gold Antifade Reagent (Invitrogen). Images were obtained using a Zeiss LSM 510 META confocal microscope (Carl Zeiss, Germany).

\section{Statistical analysis}

Statistical analyses were performed with Microsoft Excel and Sigma Plot 12. All results were tested for normality (Shapiro-Wilk test) and equal variance. The significance levels were calculated with a two-tailed unpaired $t$-test, and significant values classified as $<0.05\left(^{*}\right),<0.01\left(^{* *}\right)$ and $<0.0005\left(^{(* * *)}\right.$. Dose-response curves and $\mathrm{EC}_{50}$ values were calculated using the 4-parameter Hill model. The data were represented as the mean \pm S.E.M. (standard error of the mean) from at least three independent experiments.

\section{ACKNOWLEDGEMENTS}

We acknowledge the support by the Open Access Publication Funds of the RuhrUniversität Bochum.

\section{COMPETING INTERESTS}

The authors declare no conflict of interest.

\section{REFERENCES}

1 Buck L, Axel R. A novel multigene family may encode odorant receptors: a molecular basis for odor recognition. Cell 1991; 65: 175-187.

2 Spehr M, Gisselmann G, Poplawski A, Riffell JA, Wetzel CH, Zimmer RK et al. Identification of a testicular odorant receptor mediating human sperm chemotaxis. Science 2003; 299: 2054-2058.

3 Braun T, Voland P, Kunz L, Prinz C, Gratzl M. Enterochromaffin cells of the human gut: sensors for spices and odorants. Gastroenterology 2007; 132: 1890-1901.

4 Weng J, Wang J, Hu X, Wang F, Ittmann M, Liu M. PSGR2, a novel G-protein coupled receptor, is overexpressed in human prostate cancer. Int J Cancer 2006; 118: $1471-1480$.

5 Xu L L, Stackhouse BG, Florence K, Zhang W, Shanmugam N, Sesterhenn IA et al. PSGR, a novel prostate-specific gene with homology to a $G$ protein-coupled receptor, is overexpressed in prostate cancer. Cancer Res 2000; 60: 6568-6572.

6 Neuhaus EM, Zhang W, Gelis L, Deng Y, Noldus J, Hatt H et al. Activation of an olfactory receptor inhibits proliferation of prostate cancer cells. J Biol Chem 2009; 284: 16218-16225.

7 Maßberg D, Simon A, Häussinger D, Keitel V, Gisselmann G, Conrad H et al. Monoterpene (-)-citronellal affects hepatocarcinoma cell signaling via an olfactory receptor. Arch. Biochem Biophys 2014; 566: 100-109.

8 Zhang X, Bedigian AV, Wang W, Eggert US. G protein-coupled receptors participate in cytokinesis. Cytoskeleton (Hoboken) 2012; 69: 810-818.

9 Pluznick J L, Protzko RJ, Gevorgyan H, Peterlin Z, Sipos A, Han J et al. Olfactory receptor responding to gut microbiota-derived signals plays a role in renin secretion and blood pressure regulation. Proc Natl Acad Sci USA 2013; 110: 4410-4415.
10 Busse D, Kudella P, Grüning NM, Gisselmann G, Ständer S, Luger T et al. A synthetic sandalwood odorant induces wound-healing processes in human keratinocytes via the olfactory receptor OR2AT4. J Invest Dermatol 2014; 134: 2823-2832.

11 Manteniotis S, Wojcik S, Brauhoff P, Möllmann M, Petersen L, Göthert JR et al. Functional characterization of the ectopically expressed olfactory receptor 2AT4 in human myelogenous leukemia. Cell Death Discovery 2016; 2: 15070.

12 Veitinger T, Riffell JR, Veitinger S, Nascimento JM, Triller A, Chandsawangbhuwana C et al. Chemosensory $\mathrm{Ca} 2+$ dynamics correlate with diverse behavioral phenotypes in human sperm. J Biol Chem 2011; 286: 17311-17325.

13 Wang CL, Ng TB, Cao XH, Jiang Y, Liu ZK, Wen TY et al. CLP induces apoptosis in human leukemia $\mathrm{K} 562$ cells through $\mathrm{Ca}(2+)$ regulating extracellular-related protein kinase ERK activation. Cancer Lett 2009; 276: 221-227.

14 Sergeev IN. Calcium signaling in cancer and vitamin D. J Steroid Biochem Mol Biol 2005; 97: 145-151.

15 Lozzio CB, Lozzio BB. Human chronic myelogenous leukemia cell-line with positive Philadelphia chromosome. Blood 1975; 45: 321-334.

16 Klein E, Ben-Bassat H, Neumann H, Ralph P, Zeuthen J, Polliack A et al. Properties of the K562 cell line, derived from a patient with chronic myeloid leukemia. Int J Cancer 1976; 18: 421-431.

17 Andersson LC, Nilsson K, Gahmberg CG. K562--a human erythroleukemic cell line. Int J Cancer 1979; 23: 143-147.

18 Forchap S L, Anandacoomarasamy A, Wicks J, Di Virgilio F, Baricordi OR, Rubbini M et al. P2X7 gene polymorphisms do not appear to be a susceptibility gene locus in sporadic cases of systemic lupus erythematosus. Tissue Antigens 2008; 72: 487-490.

19 Pastore S, Mascia F, Gulinelli S, Forchap S, Dattilo C, Adinolfi E et al. Stimulation of purinergic receptors modulates chemokine expression in human keratinocytes. J Invest Dermatol 2007; 127: 660-667.

20 Cabrini G, Falzoni S, Forchap SL, Pellegatti P, Balboni A, Agostini P et al. A His-155 to Tyr polymorphism confers gain-of-function to the human P2X7 receptor of human leukemic lymphocytes. J Immunol 2005; 175: 82-89.

21 Ferrari D, Pizzirani $C$, Adinolfi E, Forchap S, Sitta B, Turchet $L$ et al. The antibiotic polymyxin B modulates P2X7 receptor function. J Immunol 2004; 173: 4652-4660.

22 Sweeney $\mathrm{G}$ et al. An inhibitor of p38 mitogen-activated protein kinase prevents insulin-stimulated glucose transport but not glucose transporter translocation in 3T3-L1 adipocytes and L6 myotubes. J Biol Chem 1999; 274: 10071-10078.

23 Heidenreich KA, Kummer JL. Inhibition of p38 mitogen-activated protein kinase by insulin in cultured fetal neurons. J Biol Chem 1996; 271: 9891-9894.

24 Dorsey JF, Cunnick JM, Lanehart R, Huang M, Kraker AJ, Bhalla KN et al. Interleukin-3 protects Bcr-Abl-transformed hematopoietic progenitor cells from apoptosis induced by Bcr-Abl tyrosine kinase inhibitors. Leukemia 2002; 16: 1589-1595.

25 Satheesh NJ, Büsselberg D. The role of intracellular calcium for the development and treatment of neuroblastoma. Cancers 2015; 7: 823-848.

26 Forchap SL, Pirmohamed M, Clark RE. Release of intracellular calcium primes chronic myeloid leukaemia cells for tyrosine kinase inhibitor-induced apoptosis. Leukemia 2012; 26: 490-498.

27 Lemoli RM, Ferrari D, Fogli M, Rossi L, Pizzirani C, Forchap S et al. Extracellular nucleotides are potent stimulators of human hematopoietic stem cells in vitro and in vivo. Blood 2004; 104: 1662-1670.

28 Wang CL, Ng TB, Yuan F, Liu ZK, Liu F. Induction of apoptosis in human leukemia K562 cells by cyclic lipopeptide from Bacillus subtilis natto T-2. Peptides 2007; 28: 1344-1350.

29 Demes B, Forchap E, Herwig H. They seem to glide. Are there aerodynamic effects in leaping prosimian primates? Z Morphol Anthropol 1991; 78: 373-385.

30 Bedi A, Zehnbauer BA, Barber JP, Sharkis SJ, Jones RJ. Inhibition of apoptosis by BCR-ABL in chronic myeloid leukemia. Blood 1994; 83: 2038-2044.

31 Apáti A, Jánossy J, Brózik A, Bauer PI, Magócsi M. Calcium induces cell survival and proliferation through the activation of the MAPK pathway in a human hormone-dependent leukemia cell line, TF-1. J Biol Chem 2003; 278: 9235-9243.

32 Boekhoff I, Breer $\mathrm{H}$. Differential stimulation of second messenger pathways by distinct classes of odorants. Neurochem Int 1990; 17: 553-557.

33 Boekhoff I, Tareilus E, Strotmann J, Breer H. Rapid activation of alternative second messenger pathways in olfactory cilia from rats by different odorants. EMBO J 1990; 9: 2453-2458.

34 Spehr J, Gelis L, Osterloh M, Oberland S, Hatt H, Spehr M et al. G protein-coupled receptor signaling via Src kinase induces endogenous human transient receptor potential vanilloid type 6 (TRPV6) channel activation. J Biol Chem 2011; 286: 13184-13192.

35 Zhang H, Tan S, Wang J, Chen S, Quan J, Xian J et al. Musashi2 modulates K562 leukemic cell proliferation and apoptosis involving the MAPK pathway. Exp Cell Res 2014; 320: 119-127.

36 Paz-Elizur T, Sevilya Z, Leitner-Dagan Y, Elinger D, Roisman LC, Livneh Z. DNA repair of oxidative DNA damage in human carcinogenesis: potential application for cancer risk assessment and prevention. Cancer Lett 2008; 266: 60-72. 
37 Lampronti I, Saab A M, Gambari R. Antiproliferative activity of essential oils derived from plants belonging to the Magnoliophyta division. Int J Oncol 2006; 29: 989-995.

38 Jaganathan SK, Mazumdar A, Mondhe D, Mandal M. Apoptotic effect of eugenol in human colon cancer cell lines. Cell Biol Int 2011; 35: 607-615.

39 Jaganathan SK, Supriyanto E. Antiproliferative and molecular mechanism of eugenol-induced apoptosis in cancer cells. Molecules 2012; 17: 6290-6304.

40 Xiao Y, Yang FQ, Li SP, Hu G, Lee SM, Wang YT. Essential oil of Curcuma wenyujin induces apoptosis in human hepatoma cells. World J Gastroenterol 2008; 14: 4309-4318.

41 Sylvestre M, Legault J, Dufour D, Pichette A. Chemical composition and anticancer activity of leaf essential oil of Myrica gale L. Phytomedicine 2005; 12: 299-304.

42 Cragg GM, Newman DJ, Weiss RB. Coral reefs, forests, and thermal vents: the worldwide exploration of nature for novel antitumor agents. Semin Oncol 1997; 24: 156-163.

43 Newman DJ, Cragg GM. Natural products as sources of new drugs over the last 25 years. J Nat Prod 2007; 70: 461-477.

44 Estey E, Döhner H. Acute myeloid leukaemia. Lancet 2006; 368: 1894-1907.

45 Burnett AK. New induction and postinduction strategies in acute myeloid leukemia. Curr Opin Hematol 2012; 19: 76-81.
46 Murgo AJ, Sistare FD. K562 leukemia cells express P2T (adenosine diphosphate) purinergic receptors. J Pharmacol Exp Ther 1992; 261: 580-585.

47 Palme D, Misovic M, Schmid E, Klumpp D, Salih HR, Rudner J et al. Kv3.4 potassium channel-mediated electrosignaling controls cell cycle and survival of irradiated leukemia cells. Pflugers Arch 2013; 465: 1209-1221.

48 Schneider CA, Rasband WS, Eliceiri KW. NIH Image to ImageJ: 25 years of image analysis. Nat Methods 2012; 9: 671-675.

49 Okazaki K, Ishikawa T, Inui M, Tada M, Goshima K, Okamoto T et al. KN-62, a specific $\mathrm{Ca}++/$ calmodulin-dependent protein kinase inhibitor, reversibly depresses the rate of beating of cultured fetal mouse cardiac myocytes. J Pharmacol Exp Ther 1994; 270: 1319-1324.

This work is licensed under a Creative Commons Attribution 4.0 International License. The images or other third party material in this article are included in the article's Creative Commons license, unless indicated otherwise in the credit line; if the material is not included under the Creative Commons license, users will need to obtain permission from the license holder to reproduce the material. To view a copy of this license, visit http://creativecommons.org/licenses/ by/4.0/

Supplementary Information accompanies the paper on the Cell Death Discovery website (http://www.nature.com/cddiscovery) 